\title{
Analysis of New Media Vision Under Ideological Education in Colleges and Universities
}

\author{
1,a Zhang Jing \\ ${ }^{1,}$ School of management ,Foreign Trade College, Chongqing Normal University, Hechuan, \\ Chongqing 401520, China \\ ajoj05319@163.com
}

Keywords: New media, ideological and political education, innovation, concept.

\begin{abstract}
Taking the innovative problems of college students' ideological and political education in new media vision as object, this paper explores the current situation and problems of ideological and political education in college, the necessity of ideological and political education innovation against new media environment and innovative guiding concept in combination with the features and functions of new media. The development and progress of ideological and political education should be promoted with the concepts of overall education, unitary dominance, inclusiveness and diversity, the instructiveness and pertinence of ideological and political education in college with service concept as guidance in new media environment, and the interactivity and equality of exploiting ideological and political education in colleges with equality concept as guidance, so as to elevate the overall moral competence and level of students.
\end{abstract}

\section{Introduction}

New media is a new form of media with the application of digital technology, network technology and mobile technology on the basis of traditional media development[1, 2, 3]; with the popularization of internet and cell-phones and the advancement of Wbe2. 0、3G technology, new media has become a new media form developed after newspapers, broadcast, television and other traditional media; with the features of high-degree autonomy, wide participation, decentralized interactivity, new media transmission draws the general public to participate in the information manufacture and transmission process, brings new virtual living style for people and positive impact and severe challenge on the moral level[4, 5]. On one hand, modern moral awareness of democracy, equality and independence are strengthened, and on the other hand, as the information transmitted through new media is complicated and overloaded in content, elusive in model, it draws great shock to college students' ideas, and brings serious challenges and good opportunities for the concepts and means of traditional ideological and political education. How to innovate ideological and political education of college students in the informationized and globalized situation has become an issue with great value.

This paper makes qualitative and quantitative analysis on the influence of new media on the morality of college students through questionnaires and interviews, using the multidisciplinary cross-over study of linking theory with practice, Marxist ethics, communication science and politics, education and other disciplines, exploring the innovation problem of college students' ideological and political education from the vision of new media; through building moral website, blog, short message education platform and other means, efficient ways have been used to probe into the application of new media in real ideological and political education, providing real basis for studies.

\section{Production, development and function of new media}

New media, comparatively speaking of traditional media, is a new form developed after newspaper, broadcast, television and other traditional media, a new form applying digital, network and mobile technology on the basis of traditional media development. The new media in this paper adopts the broad and open connotation, including the media of new type lately developed. The 
development of new media shows two features. The first is that protogenetic new media forms spring up continuously. Forms like e-mail, BBS, personal homepage, short messages as well as blog, podcast, forum community and other forms based on new information network emerge endlessly. The second is that, new media forms are produced based on new information network technology and the innovation and integration of traditional media, such as internet radio, internet television, internet newspaper, mobile newspaper, and so on, which enriches media forms and expands the living space of traditional media. In view of the developing trend of the internet and media integration, new media, broadly speaking, can be called as internet media, whose developing trend can be summarized into two aspects of society networked and internet socialization.

The development trend of society networked and internet socialization has not only exerted great influence on media field, but also hastened new media culture with information technology as support and new media as medium, which has changed the traditional producing and existing way, deeply influences the organizational and behavioral ways of society, government and citizens.

The basic types of new media can be divided into internet new media, cell-phone new media and digital TV new media. Internet new media are various types built on internet, including all kinds of websites, blogs, podcasts, wikis, web TVs, network broadcasts, network newspapers, and so on. Cell-phone new media is a form with cell-phones as receiving terminal, including short message, mobile newspapers, mobile TVs, and so on. Television new media is built on the basis of digital TV, including digital TVs, IPTV, mobile TVs and outdoor new media, and so on.

Comparing with traditional media, new media has following features: (1)interactivity and instantaneity of decentralization; (2) high-degree of autonomy and participation; (3) global sharing and comparatively closed socialization; (4) personalization and differences of receivers; (5) regression and formation of new interpersonal transmission model; (6) large volume and diversified information; (7) multimedia and hyper text.

New media is based on information network technology, triggers the expansion of time and space, building a flowing space and limitless time and virtual daily world, and becoming important social life and playground for modern people; traditional unitary physical living space develops into dual living world of real and virtual life, which changes the unitary and fixed model of traditional social mental life; network time and space are also "real time and space" for people's spiritual communication and interaction, as well as "virtual reality" . New media has changed people's way of exchanges. Building public field has propelled social democracy; through collecting opinions on the two sessions of netizens and other people, it improves, removes and enhances people's enthusiasm of participating in the administration and discussion of state affairs, as well as the political rights and social responsibilities that they enjoy. New media overcomes the shortcomings of information delay and omissions, the model of single-direction dissemination and the barrier of unable to reply people's inquiries of traditional media, making media supervision by public opinions more comprehensive and sufficient. The application and development of new media has exerted positive impetus for accelerating socialist democratization process in new times and promoting the construction of socialist democracy in our country. In the process of information transmission and public opinion formation, traditional transmission situation has changed and become information exchange platform that can express the public voice rapidly. In modern times, public media has made the formation and development of opinions normal and purposeful. The openness and interactivity of new media makes every user has the chance to be the speaker in public opinion. The secretiveness and rapidity of new media has not only quickened the formation and development process of public opinions, but also made the production of public voice beyond control.

\section{Innovation of guiding concepts of college students' ideological and political education in new media vision}

The virtual space brought by new media is totally different from many features of physical reality.

"In the virtual environment created by new media, people's thinking floats in virtual space, gets rid of the constraints of material, immersing in the virtual world filled with digital emotions. As there are 
differences between virtual space and physical real space, we believe that, no matter how large the inclusiveness there is, virtual space cannot substitute physical space, and not anything in moral work of physical space can be solved on internet. Moral problems are usually complicated and diversified, and superficial communication cannot show the problems obviously and accurately. As is shown in Figure 1, in virtual space, the basic moral link of "educators - communication - educated --information" also exists, and therefore, to develop ideological and political education for new media in virtual space will get the optimal effect that ideological and political education cannot get in unitary virtual space. The combination of ideological and political education in both virtual space and real space can be shown in all the aspects of combination in goal, content, method, means, and effect.

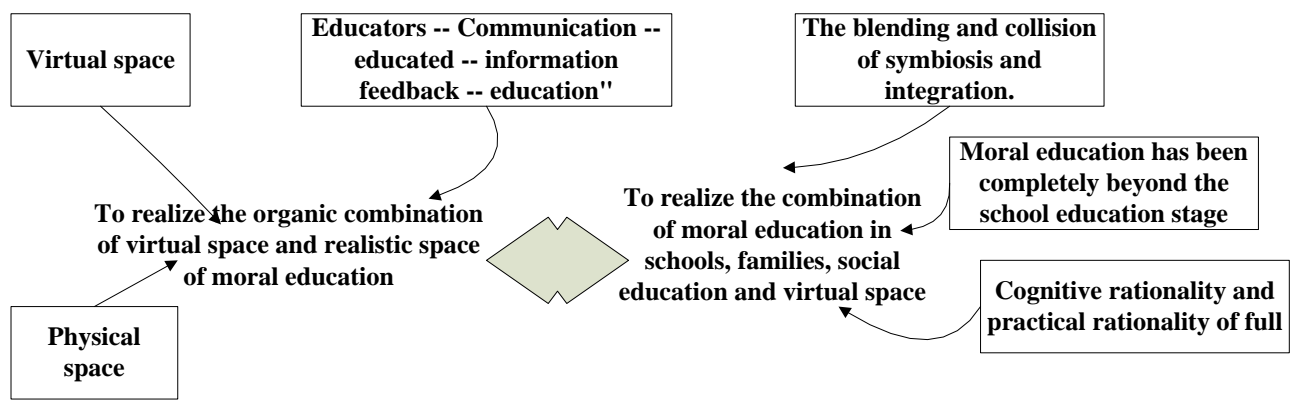

Figure 1. Overall education concept process

The openness of new media inevitably produces contradictions and conflicts with closed traditional ideological and political education model; education is not isolated, which is not only closely related to the education of other aspects, but also closely linked to the whole society. However, for a long time, our school ideological and political education and social ideological and political education have formed comparatively independent enclosed system, and thus, in front of the openness of new media, traditional ideological and political education system cannot fill the gap. In the new media environment, the simple school ideological and political education should be expanded to family, community, society and even new media themselves, making the society shoulder ideological and political education tasks and responsibilities together; at the same time, the network evaluation system of school, society, family should be perfect. The structural fall between ideological and political education and new media, as well as the conflicts between information openness and ideological and political education enclosing should be reduced as much as possible. Objectively, the influence of new media on schools, families, society, and students is huge, and it also has changed the living way of human beings in all dimensions. In the long run, if ideological and political education shrinks with each passing day in the new media, moral problems will be faced with disastrous consequences. As a result., ideological and political education system should advance with the times; if not, its survival and development will become a problem. In the new media environment, ideological and political education should realize the changes from the sole school education to the education of school, family and society combined with new media virtual space education.

Establish concepts of unitary domination, inclusiveness and variation: As is shown in Figure 2, it shows the establishment of concepts of unitary domination, intolerance and variation; in the environment of new media transmission, the intersection and crash of oriental and western cultural thoughts are more direct; the new media transmission environment is a comparatively complex cultural environment with multicultural interaction and impact of many thoughts. As the disseminators and receivers are wide and initiative, the effective control measures of traditional media in value guidance, such as blocking information source, controlling transmission channels, selecting information streams and other means are hard to realize in new media; therefore, to use socialist core value system to guide new media culture is needed in optimization of new media transmission environment, as well as the real needs of innovating ideological and political education under new media environment. 


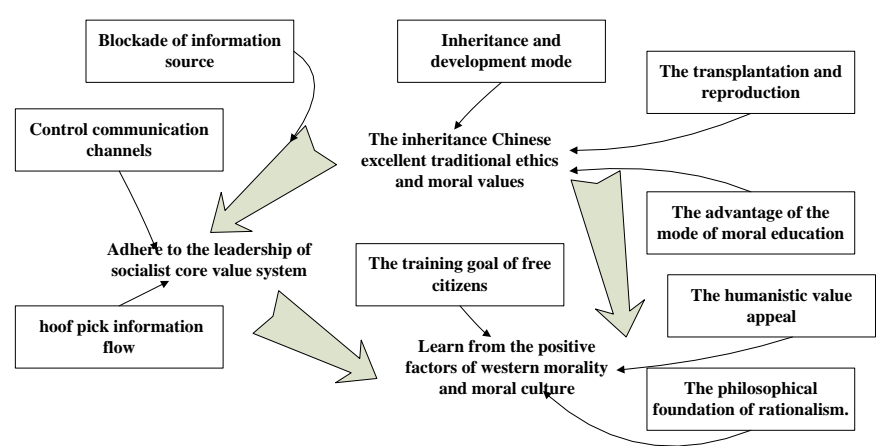

Figure 2. Establishment of concepts of unitary domination, inclusiveness and variation

Instructiveness and pertinence of ideological and political education in colleges with the service concept under new media environment as guidance:Taking the service concept under new media environment as guidance can manifest the instructiveness of ideological and political education in colleges. Large amount of information has caused more and more psychological problems, and even indifference to life, which influences the effectiveness and instructiveness of ideological and political education of college students. Taking the service concept under new media environment has become the highest priority. Therefore, the education concept of serving students should be comprehensively built, and service mechanism should be built to strengthened for college students, interactive system be built; and the feedback should be in time so as to prevent and control psychological problems. Through the platform of new media network, the service objects can be fully understood, service awareness be firmly established, service system be scientifically constructed, service level be fully elevated, effectiveness of colleges students' ideological and political education be increased, and in this way, students can reach their prime and develop well.

Taking the service concept under new media environment as guidance can manifest the pertinence of ideological and political education in colleges. New media has features of cross time and space, convenience and virtuality, in which the enthusiasm of active participation in ideological and political educational activities fades, educates presenting state of out of control and college ideological and political education falling in confusion. To gain excellent effect in college students' ideological and political education, service concept in new media environment should be defined to show the pertinence of ideological and political education in colleges. For this, college ideological and political education should take service concept as guidance; educators should concern the living situation of college students and get close to them, so as to provide them with service; they should also start from the realities of colleges students' thinking, politics, morality, laws and psychology, using new media, to have a clear knowledge of the inner world of college students through various forms of cultural carriers, mobile carriers and managing carriers, as well as face-to-face communication and exchanges and spiritual collisions, in which way, ideological and political education can be carried out purposefully, attraction and infection of ideological and political education in colleges can be elevated, and the pertinence and effectiveness can be strengthened.

Interactivity and equality of ideological and political education in colleges with the equality concept under new media environment as guidance:As is shown in Figure 3, the interactivity of ideological and political education in colleges with equality concept in new media environment is manifested. In ideological and political education, the subjects and objects of education are put at equal places and the information feedbacks of objects are focused on; through the interaction, dialogues and exchanges of education subjects and objects, the initiative of education objects' participation in and reception of ideological and political education can be motivated; with multiple education means and propagation media, thought and information is transmitted, and the interestingness, permeability and infectivity can be increased in ideological and political education. The subjects and objects of traditional ideological and political education in colleges are obviously in different places; there is oppositions and barriers between the educators and the objects; educators are dominantly infuse one-way information to students, making the latter lose their independency and produce the desire to pursue equality and interactivity. In new media environment, college 
ideological and political education should become an interactive system, in which factors interact and exchange with each other and with new media environment. The equality of new media satisfies and caters to the inner needs of college students and puts forward unprecedented challenges to the authority and dominance of ideological and political education. To carry out the equality concept under new media environment is favorable for creating the harmonious environment between educators and students, for their equal interactions and making friends, and for harmonious coexistence, mutual respect, jointly discussion and bilateral interaction. Under new media environment, one person is equipped with two identities of both physical subject and virtual subject, and ideological and political education under new media environment in colleges should take the equality concept as guidance to update the subject view, to recognize the subjectivity of educators and students, and to insist the dialectical unity of real subjects and virtual subject in interaction. Under new media environment, the subjectivity of subjects and objects tends to be equal. New media environment provides subjects and objects with equal opportunities to communicate, which stimulates the subjectivity of the two parties, and fully opens the autonomy, initiative and creativity of them. To implement the equal concept in new media environment, the students' subjectivity should be fully noticed and emphasized, to realize the conversion from heteronomy to self-discipline, and the subjective awareness of students should be reinforced and cultivated, so as to develop the subjective potential and shape the subjective personality.

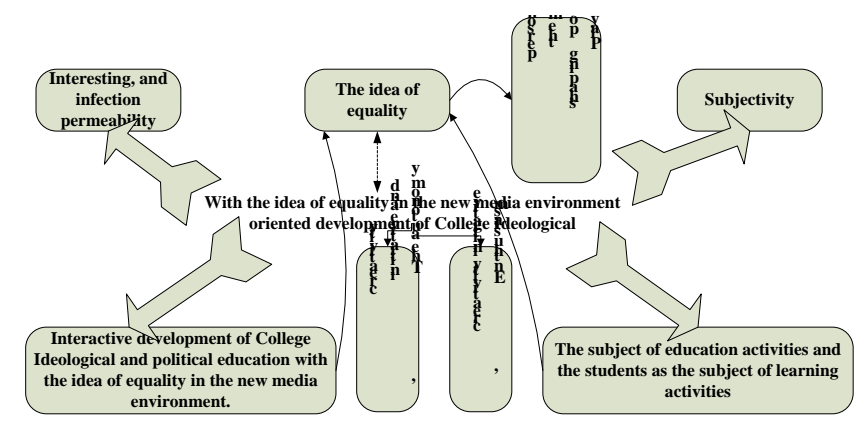

Figure 3 Ideological and political educational process of equality concept under new media

\section{Conclusions}

New media can directly fulfill college students' desire for innovation and knowledge; as for the media form itself, it provides ways to contact new stuff for college students. New media endows new connotation for colleges students' learning and living, and at the same time, generates great influence on their thinking modes, which makes the coexistence of opportunities and challenges of ideological and political education in college students under the new situation. Under the multiple environment of coexistence of virtuality and reality, the development and progress of ideological and political education should be promoted with the concepts of overall education, unitary dominance, inclusiveness and diversity, the instructiveness and pertinence of ideological and political education in college with service concept as guidance in new media environment, and the interactivity and equality of exploiting ideological and political education in colleges with equality concept as guidance, so as to elevate the overall moral competence and level of students.

\section{References}

[1] Xie Xiaojuan. Five changes of college ideological and political education concepts since reform and opening up [J]. Ideological and political education, 2009, (25): 3.

[2] Gong Chengbo. Outline of new media [M] Beijing: China Radio and TV Press, 2009.

[3] Yu Haibo. Challenges and countermeasures faced by college ideological and political education under new media environment [J]. Education and vocation, 2011, 11: 19-21 
[4] Deng Hongbin. Enforce college students' ideological and political education effectiveness with application of new media [J]. College party construction and ideological education, 2011, 13: 112-114

[5] Zhangjun. Impetus generation of modern ideological and political education under new media environment [J]. College party construction and ideological education, 2011,07: 18-22

[6] Ding Huimin. Study on the directive of college students' ideological and political education under new media environment [J]. College party construction and ideological education, 2010, 08: 23-25 [7] Tian Guangcan. Study on ideological and political education under new media influence [J]. College party construction and ideological education, 2009, $\quad 33: 34-38$.

[8] Tang Qiong. Explorative analysis of the function in ideological and political education of college students [J]. College party construction and ideological education, 2010, 04: 8-11.

[9] Yu Shubiao. Countermeasures of ideological and political education under new media influence [J]. College party construction and ideological education, 2010,12:17-19. 